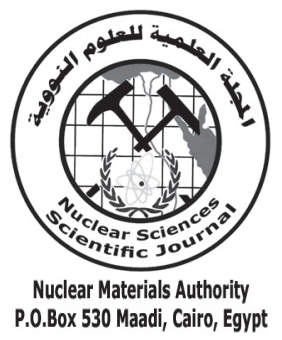

ISSN 2314-5609

Nuclear Sciences Scientific Journal

vol. 2, p 175 - 182

2013

\title{
KINETICS OF LEACHING PROCESS OF SELLA URANIUM ORE MATERIAL, SOUTH EASTERN DESERT, EGYPT
}

YASSER M. KHAWASSEK and MOHAMED H. TAHA

Nuclear Materials Authority, P.O Box 530 El Maadi, Cairo,Egypt

\begin{abstract}
The leaching of uranium from Sella uranium ore using hydrochloric acid solution has been studied. The effect of different parameters such as leaching time, hydrochloric acid concentration, liquid/ solid mass ratio, reaction temperature, mechanical stirring speed are investigated in order to optimize various process parameters for maximizing the recovery of uranium. The maximum percentage uranium leaching of $96 \%$ is achieved after $15 \mathrm{~min}$ of contact time leaching using 3.0 M hydrochloric acid and 4/ 1 liquid/ solid mass ratio at $26{ }^{\circ} \mathrm{C}$ with $400 \mathrm{rpm}$ mechanical stirring speed.

The experimental data are well interpreted with a shrinking core model with diffusion control through a porous product layer. By using the Arrhenius expression, the apparent activation energy for the uranium leaching reaction is evaluated.
\end{abstract}

\section{INTRODUCTION}

In the last few decades, the Nuclear Materials Authority of Egypt (NMA) conducted comprehensive programs for the exploration of uranium mineralization in Egypt. These programs led to the discovery of some uranium mineralization related to the so called younger granites in the Eastern Desert. In the extreme south eastern part of Egypt as Halaib environ, a new uranium mineralization has been lately discovered at Gabal El Sella. The study area of Gabal El Sella at Halaib environ is located at about $20 \mathrm{~km}$ west of Abu Ramad City covering an area of about $128 \mathrm{~km}^{2}$. It is roughly bound by long. $36^{\circ} 8^{\prime}-36^{\circ} 17^{\prime} \mathrm{E}$ and lat. $22^{\circ} 13^{\prime}-23^{\circ} 20^{\prime} \mathrm{N}$ ( El-Afandy et al.,2002 \& Ibrahim et al.,2003).

Leaching process is the dissolution of uranium from the uranium containing minerals in the ore. The selection of leaching procedure for dissolving uranium minerals is dependant in part on the physical characteristics of the ore such as type of mineralization, ease of liberation and the nature of other constituent minerals presents ( Merritt,1971). During the past few decades, different types of leaching processes based on acid leaching and alkaline leaching methods have been developed for processing uranium ore of different characteristics (Gupta and Mukherjee,1990). Due to the relatively presence of the clayey materials in El Sella ore materials, some difficulties are arised during the filtration and washing of the leach slurry using sulfuric acid in the leaching process at Inshas Pilot Plant Unit which may lead to loss of some valuable uranium (Khawassek,2011).

Chloride system in hydrometallurgy has been used for the treatment and recovery of precious metals for many years especially from clays because of the ease of filtration slurries. The most serious problem connected with the use of hydrochloric acid is the severe corrosion. However, the development of corrosion resistant plastics and rubbers partially solved this problem so that the corrosion is no longer a prohibitive factor ( Regina and Okechukwu,2012 ; Ucar,2009). Hydrochloric acid, a strong acid has relatively small mol- 
ecule size. This may be expected to have a faster diffusion rate than some other acids in the leaching process. The residence time for the leaching process is kept low and the uranium recovery rates are high (Zafar et al.,2006). In addition, hydrochloric acid do not represent a problem with clays compared to sodium or ammonia based solutions. It has been found that $\mathrm{pH}$ must be kept below 2 for optimum leaching rates, above 4 the uranium will not dissolve and recovery is therefore not possible (Kasper et al.,1979).

Many precious metals have been leached from their ores using hydrochloric acid such as batch leaching of uranium ore in Canada ( Haque and Laliberté, 1987), dissolution of total gold from Ijero-ekiti (Nigeria) gold ore deposit (Baba et al.,2011), leaching of $\mathrm{TiO}_{2}$ from Egyptian ilmenite (El-Hazek et al.,2007), leaching of nickel and cobalt from Chinese laterite ore (Jinhui et al., 2012). Cobalt and copper have been leached successfully by $\mathrm{HCl}$ from $\mathrm{Co}-\mathrm{Cu}$ ores in the Democratic Republic of Congo (Clotilde and Mulaba, 2011) and phosphorus has been leached from high phosphorus iron ores in China ( Wen-tang et al.,2011).

The dissolution study of various ores in inorganic acids has been investigated in details ( Morse and Arvidson, 2002; Liang et al., 2005 and Baba et al.,2007). Kinetic leaching of bastnaesite concentrate, rutile ore, and ukpor clay by using hydrochloric acid were represented by shrinking core model with diffusion through a porous product layer (Bian et al.,2011 ; Alafara et al.,2009 ; Regina and Okechukwu,2012).

Since there is virtually no reported work on the leaching or dissolution kinetics of Sella uranium ore, this work is therefore expected to provide useful data on the kinetic parameters on the leaching of the ore.

\section{EXPERIMENTAL}

\section{Materials}

A representative sample of Sella uranium ore sample is obtained from an ore deposit of G. El Sella area, Halaib environ at about 20 km west of Abu Ramad City, Egypt. The ore sample was crushed with a jaw crusher until the whole sample passed through $150 \mu \mathrm{m}$ sieve. Then the sample is thoroughly mixed, and then dried in an electric oven at $110^{\circ} \mathrm{C}$ for 24 hours, then cooled and stored for further use. The chemical analysis of the ore sample is shown in Table 1.

Table 1: Chemical analysis of Sells uranium ore sample

\begin{tabular}{lrrr}
\hline & & & \\
& & & \\
& & & \\
\hline $\mathrm{SiO}_{2}$ & 58.1 & $\mathrm{SO}_{3}$ & 0.4 \\
$\mathrm{CaO}$ & 2.9 & $\mathrm{TiO}_{2}$ & 2.9 \\
$\mathrm{Fe}_{2} \mathrm{O}_{3}$ & 9.8 & $\mathrm{~K}_{2} \mathrm{O}$ & 2.1 \\
$\mathrm{Al}_{2} \mathrm{O}_{3}$ & 16.0 & $\mathrm{Na}_{2} \mathrm{O}$ & 1.3 \\
$\mathrm{MgO}$ & 1.7 & $\mathrm{U}$ & 500 \\
& & & $\mathrm{ppm}$ \\
\hline
\end{tabular}

\section{Methods}

The leaching experiments are performed in a $500 \mathrm{ml}$ glass reactor. A mechanical stirrer is used and a thermostat is employed to keep the reaction medium at constant temperature. In the leaching process, hydrochloric acid solution put into reactor. After the desired reaction temperature is reached, a specific amount of the sample is added to the solution and the stirring started. After a certain period of time, the solution is filtered. The amounts of uranium in the leaching filtrate were analyzed spectrometrically by the Arsenazo III ( Marczenko,1976). The dissolution percent of uranium was calculated by the following equation;

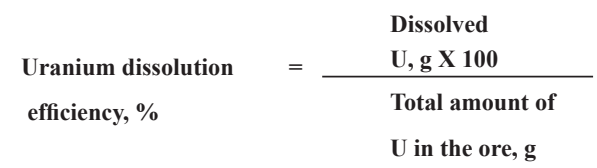




\section{RESULTS AND DISCUSSION}

\section{The parameter Effect}

The following is a discussion of the results obtained when Sella uranium ore is subjected to dissolution with hydrochloric acid solution. The effects of reaction time, mechanical stirring speed, hydrochloric acid concentration, liquid/ solid ratio and reaction temperature on the dissolution process have been investigated.

\section{Effect of reaction time}

The effect of reaction time on the dissolution rate, using $400 \mathrm{rpm}$ stirring speed, $3.0 \mathrm{M}$ hydrochloric acid concentration, room temperature, 150-63 $\mu \mathrm{m}$ particle size fractions, and liquid/ solid ratio $30 \mathrm{ml} / 10 \mathrm{~g}$, is shown on Fig. 1 as a relationship between the percentage uranium dissolution efficiency and contact time. An increase in reaction time above 15 min has a minor effect on the amount of weight loss or on percent increase in uranium content. Therefore, in all proceeding experiments, the reaction dissolution time was kept at $15 \mathrm{~min}$.

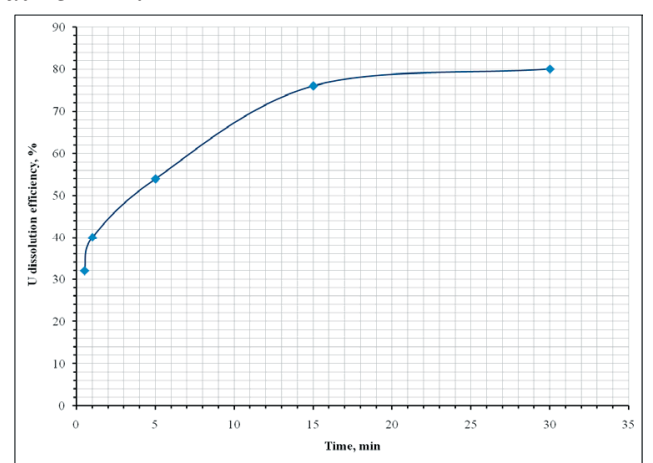

Fig.1: Effect of contact time on the uranium dissolution efficiency \% (stirring speed: $400 \mathrm{rpm}$; particle size: 150 $63 \mu \mathrm{m}$; L/S mass ratio: $30 \mathrm{ml} / 10 \mathrm{~g}$; $[\mathrm{HCl}]: 3.0 \mathrm{M}$; temperature: $26 \mathrm{oC}$ )

\section{Effect of hydrochloric acid concentration}

The effect of hydrochloric acid concentration on the Sella uranium dissolution process at a dissolution time of $15 \mathrm{~min}$, a stirring speed of $400 \mathrm{rpm}$, a temperature of $26^{\circ} \mathrm{C}$, a particle size fraction of $150-63 \mu \mathrm{m}$, and a liquid/ solid ratio, $30 \mathrm{ml} / 10 \mathrm{~g}$, is investigated. As seen from the experimental results given on Fig. 2, the uranium percentage dissolution efficiency is increased by increasing hydrochloric acid concentration up to $3.0 \mathrm{M}$ while further increasing has rare effect on the dissolution process. This may be due to the increase of the $\mathrm{H}^{+}$ions in the solution which may lead to the dissolution of some guange materials. Consequently, 3.0 M hydrochloric acid is the concentration choice for the subsequent Sella uranium ore dissolution experiments.

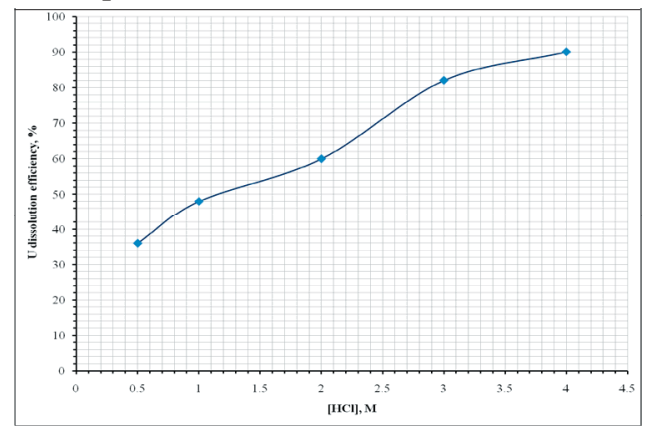

Fig.2: Effect of hydrochloric acid concentration on the uranium dissolution efficiency \% (time: $15 \mathrm{~min}$; stirring speed: $400 \mathrm{rpm}$; particle size: $150-63 \mu \mathrm{m}$; L/S mass ratio: $30 \mathrm{ml} / 10 \mathrm{~g}$; temperature: $26 \mathrm{oC}$ )

\section{Effect of liquid/ solid ratio}

Figure 3 shows the effect of liquid/ solid ratio on the uranium dissolution process at a reaction time of $15 \mathrm{~min}$, a stirring speed of 400 $\mathrm{rpm}$, an acid concentration of $3.0 \mathrm{M}$, a temperature of $26^{\circ} \mathrm{C}$ and a $150-63 \mu \mathrm{m}$ particle size fraction. The experimental results show a continuous increasing of the weight loss with an increase of the liquid/ solid ratio. That may be due to the decrease of solution bulk density causing increase in the migration of different ions to the liquid medium. Therefore, $30 \mathrm{ml} /$ $10 \mathrm{~g}$, hydrochloric acid/ uranium ore mass ratio represents the preferred condition for the other uranium ore dissolution experiments.

\section{Effect of temperature}

The effect of reaction temperature on the dissolution process is investigated for the temperatures of $20,30,40$ and $50^{\circ} \mathrm{C}$ at a reaction 
time of $15 \mathrm{~min}$, a stirring speed of $400 \mathrm{rpm}$, an acid concentration of $3.0 \mathrm{M}$, a particle size fraction of $150-63 \mu \mathrm{m}$, and a liquid/ solid ration, $30 \mathrm{ml} / 10 \mathrm{~g}$. As can be seen on Fig. 4, the percentage uranium dissolution efficiency is slightly increased by increasing the reaction temperature from 20 to $50^{\circ} \mathrm{C}$. Therefore, room temperature represents the workable temperature for the other factors experiments.

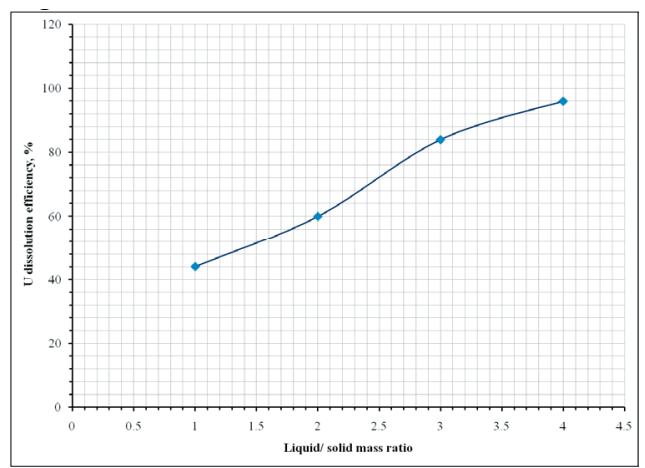

Fig.3: Effect of liquid/ solid mass ratio on the uranium dissolution efficiency \% (time: $15 \mathrm{~min}$; stirring speed: $400 \mathrm{rpm}$; particle size: $150-63 \mu \mathrm{m}$; $[\mathrm{HCl}]: 3.0 \mathrm{M}$; temperature: $26 \mathrm{oC}$ )

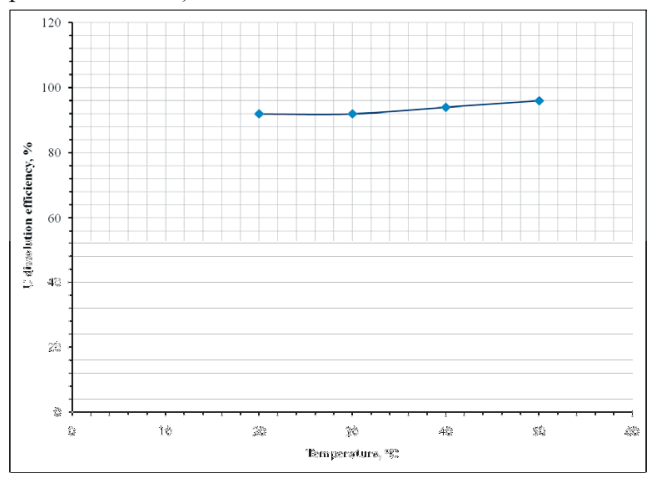

Fig.4: Effect of temperature on the uranium dissolution ef ficiency \% (time: $15 \mathrm{~min}$; stirring speed: $400 \mathrm{rpm}$; particle size: $150-63 \mu \mathrm{m}$; [HCl]: $3.0 \mathrm{M}$; L/S mass ratio: $30 \mathrm{ml} / 10 \mathrm{~g}$ )

\section{Effect of stirring speed}

To study the effect of mechanical stirring speed on the Sella uranium ore dissolution by 3.0 M hydrochloric acid several experiments are carried at different mechanical stirring speeds from $200 \mathrm{rpm}$ to $800 \mathrm{rpm}$ while the other experimental conditions are kept con- stant using 15 min reaction dissolution time at room temperature, liquid/ solid ratio 30 $\mathrm{ml} / 10 \mathrm{~g}$, and a particle size $150-63 \mu \mathrm{m}$. The experimental results are given on Fig. 5 as a relationship between uranium dissolution efficiency $\%$ and mechanical stirring speed. The mechanical stirring of the reactants has slight effect on the dissolution process (Fig.5). Thus the change in stirring speed has no effect on the Sella uranium ore dissolution by hydrochloric acid.

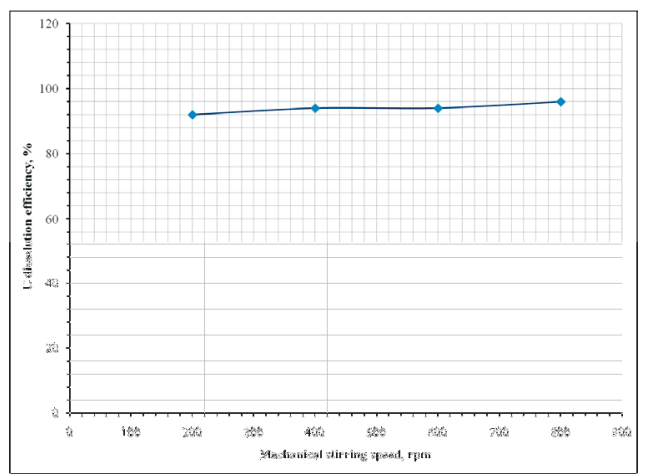

Fig.5: Effect of mechanical stirring speed on the uranium dissolution efficiency \% (time: $15 \mathrm{~min}$; temperature: 26 oC; particle size: 150-63 $\mu \mathrm{m}$; [HCl]: $3.0 \mathrm{M}$; L/S mass ratio: $30 \mathrm{ml} / 10 \mathrm{~g}$ )

\section{Dissolution Kinetic Analysis}

The dissolution of mineral from Sella uranium ore takes place through the following stages:

1. Diffusion of reactant through the diffusion layer

2. Adsorption of the reactant on the solid

3. Chemical reaction between the reactant and the solid

4. Desorption of the product from the solid

5. Diffusion of the product through the diffusion layer.

Any of these may be rate controlling depending on its relative speed to the others.

Understanding the mechanism of a leaching system is the main objective of this study. Leaching of mineral particle may be described by a number of reaction models already proposed in the literature. 
In order to establish the kinetic parameters and rate-controlling step for the dissolution of Sella uranium ore using hydrochloric acid, the experimental data can be analyzed according to the heterogeneous reaction models.

According to the model, the reaction between a fluid and a solid may be written as:

$$
\text { F (fluid) }+ \text { bS (solid) } \rightarrow \text { Products }
$$

The rate of the ore dissolution is analyzed with the shrinking core models based on the assumption that the concentrate is a homogenous spherical solid phase (Levenspiel, 1999 ; Sohn,2003). The shrinking core model considers that the leaching process is controlled either by the diffusion of reactant through the solution boundary layer, or through a solid product layer, or by rate of the surface chemical reaction. The simplified equations of the shrinking core model when either surface or the diffusion chemical reactions are the slowest step can be expressed as follows, respectively (Aydogan et al.,2005):

$$
\begin{aligned}
& \mathrm{K}_{1} \mathrm{t}=1-3(1-\alpha)^{2 / 3}+2(1-\alpha) \\
& \mathrm{K}_{2} \mathrm{t}=1-(1-\alpha)^{1 / 3}
\end{aligned}
$$

Where $\alpha$ is the fraction of uranium ore concentrate reacted at contact time, $\mathrm{t}$ and $\mathrm{k}_{1}, \mathrm{k}_{2}$ are the apparent reaction rate constants.

Equation (1) reveals that if the diffusion through the product layer controls the leaching rate, there must be a liner relation between the left side of equation and time. The slope of the line is the rate constant, $\mathrm{k}_{1}$. It must be directly proportional to $1 / \mathrm{r}^{2}$ ( $\mathrm{r}_{\mathrm{o}}$ is the initial radius of the solid particle). If the surface reaction controls the rate, the relation between the left side of equation (2) must be linear. The slope of this line is called the apparent rate constant, $\mathrm{k}_{2}$ and must be directly proportional to $1 / \mathrm{r}_{\mathrm{o}}$ (Aydogan et al.,2005) .

The two shrinking core models could be examined at different temperatures as shown on Figs. 6 and 7. From these figures it is clear that only equation (1) has been found to give a perfect straight line with average correlation of 0.99 . The resulting slopes of each line on Figure 5 were calculated and these represent the apparent reaction rate constants $\mathrm{k}_{1}$. The different values of the apparent rate constant, $\mathrm{k}_{1}$ at different temperatures and their corresponding correlation coefficient rate are summarized in Table 2.

The apparent rate constant, $\mathrm{k}$, was used to obtain the Arrhenius relation as shown on Fig. 8 , and may be expressed as follows:

$$
\mathrm{k}=\operatorname{Aexp}-(\mathrm{Ea} / \mathrm{RT})
$$

where $\mathrm{k}$ is the overall rate constant in $\min ^{-1}, \mathrm{~A}$ is the frequency factor in $\mathrm{min}^{-1}, \mathrm{Ea}$ is the activation energy in $\mathrm{J}$ $\mathrm{mol}^{-1}, \mathrm{R}$ is universal gas constant $\left(8.314 \mathrm{~J} \mathrm{k}^{-1} \mathrm{~mol}^{-1}\right)$, and $\mathrm{T}$ is the reaction temperature in $\mathrm{K}$.

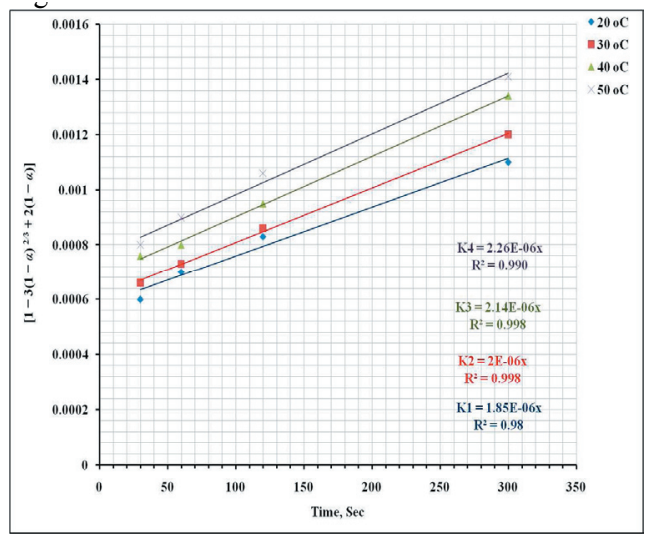

Fig. 6: Effect of temperature on the function $[1-3(1-\alpha) 2 / 3$ $+2(1-\alpha)$ ] (particle size: $150-63 \mu \mathrm{m}$; $[\mathrm{HCl}]: 3.0 \mathrm{M} ; \mathrm{L} / \mathrm{S}$ mass ratio: $30 \mathrm{ml} / 10 \mathrm{~g}$; mechanical stirring speed: $400 \mathrm{rpm}$ )

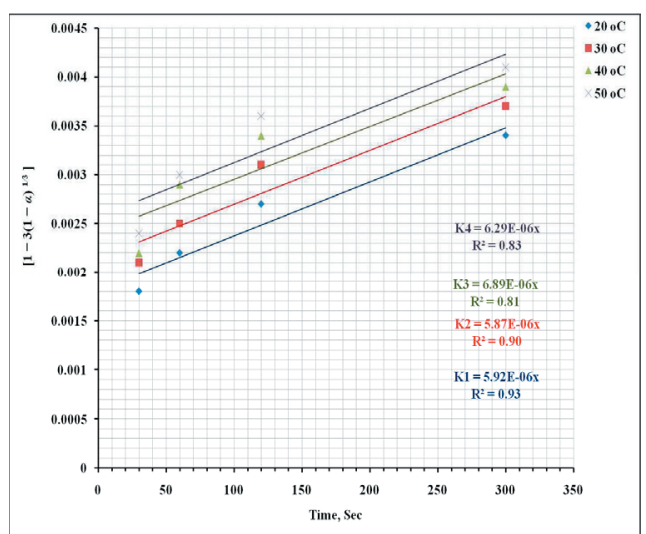

Fig.7: Effect of temperature on the function $[1-(1-\alpha)$ 1/3] (particle size: $150-63 \mu \mathrm{m}$; [HCl]: $3.0 \mathrm{M}$; L/S mass ratio: $30 \mathrm{ml} / 10 \mathrm{~g}$; mechanical stirring speed: $400 \mathrm{rpm}$ ) 
Table 2: The value of the apparent rate constant,K1, min-1 with the correlation coefficient at different temperature range

\begin{tabular}{lrc}
\hline Temp. $\left({ }^{\circ} \mathrm{C}\right)$ & $\begin{array}{r}\text { Apparent } \\
K_{1}, \min ^{-1}\end{array}$ & $\mathbf{R}^{2}$ \\
\hline 20 & 1.85 & $\mathbf{0 . 9 8}$ \\
30 & 2.00 & 0.99 \\
40 & 2.14 & 0.99 \\
50 & 2.26 & 0.99 \\
\hline
\end{tabular}

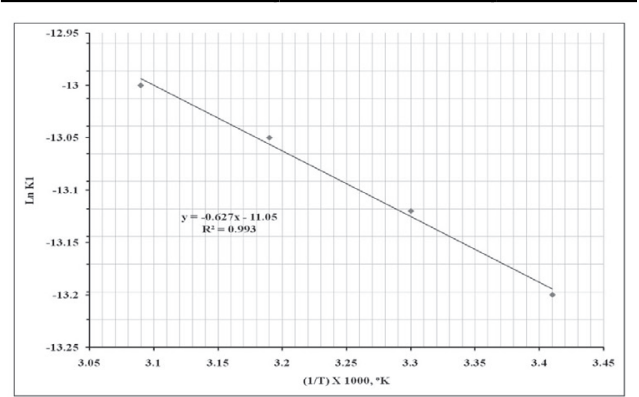

Fig. 8: Relation between $\ln \mathrm{K} 1$ and (1/T) oK X 1000

From the experimental data above, the activation energy, Ea, of $5.21 \mathrm{~kJ} / \mathrm{mol}$ is calculated for the dissolution process.

Since the diffusion controlled reaction would show a slight increase in the rate with increasing the agitation speed and typically has an activation energy $\leq 25 \mathrm{~kJ} \mathrm{~mol}^{-1}$, so the calculated activation energy suggests a diffusion controlled process for Sella uranium ore dissolution in hydrochloric acid.

The results of recent studies showed that some diffusion controlled reactions could have unusually high activation energy. For instance, the activation energy for the diffusion controlled dissolution of titanium and iron from ilmenite in hydrochloric acid solution are reported as 48.9 and $53.7 \mathrm{~kJ}$ mol-1, respectively (Tsuchida et al.,1982), and that from a Nigerian ilmenite in hydrochloric acid solution are also reported as $62.4-67.1 \mathrm{~kJ}$ mol1 (Olanipekun, 1999). Similarly, the activation energy for the diffusion controlled hydrochlo- ric acid leaching of iron from bauxite varied from 62 to $79 \mathrm{~kJ} / \mathrm{mol}$ for different particle size fractions (Paspaliaris and Tsolakis,1987). On closer examination, it appears that the rate controlling mechanism of heterogeneous dissolution reactions is sometimes better predicted from plots of the kinetic equations than from the activation energy values.

\section{CONCLUSION}

In this study, the leaching of uranium from Sella uranium ore using hydrochloric acid solution has been investigated. The results show that the reaction rate increases with time, hydrogen ion $\left[\mathrm{H}^{+}\right]$concentration, Liquid/ solid mass ratio, while leaching temperature and stirring speed have a slight effect on the leaching rate.

The leaching data shows that $96 \%$ of uranium could be leached from Sella uranium ore after 15 min using 3.0 M hydrochloric acid and 4/ 1 mass / liquid mass ratio at room temperature with mechanical stirring of $400 \mathrm{rpm}$. The kinetics of the leaching process is found to be governed by the shrinking core model as the diffusion controlled process. The mathematical treatment for the obtained data shows that, the Sella uranium ore leaching by hydrochloric acid activation energy is $5.21 \mathrm{~kJ} / \mathrm{mol}$.

\section{Nomenclature}

$\mathrm{A}$ is the frequency factor in $\mathrm{min}^{-1}$; Ea Activation energy $(\mathrm{kJ} / \mathrm{mol})$; $\mathrm{k}$ Reaction rate constant $\left(\min ^{-1}\right) ; \mathrm{k}_{1}, \mathrm{k}_{2}$ apparent reaction rate constants; L/S Liquid to Solid ratio; M mole/liter ; t Time (min); T Recorded temperature ; $r_{\text {o }}$ Initial radius of the solid particle ; R Universal gas constant, $8.314 \mathrm{~J} \mathrm{~mol}^{-1} \mathrm{~K}^{-1}$; rpm Revolutions per minute; $\mathrm{R}^{2}$ Coefficient of determination (a statistical value); $\alpha$ Fraction of uranium ore concentrate reacted at contact time ; $\mu \mathrm{m}$ Micro meter 


\section{REFERENCES}

Alafara, A. B.; Folahan, A. A.; Emmanuela, E. T., and Rafiu, B. B.,2009. Dissolution kinetics and leaching of rutile ore in hydrochloric acid. J. Min. \& Materials Characterization \& Engineering, 8 (10), 787-801.

Aydogan, S.; Aras, A., and Cambazoglu, M., 2005. Dissolution kinetics of sphalerite in acidic ferric chloride leaching. Chem. Engr. J., 114, 67-72.

Baba, A. A.; Adekola, F. A.; Dele-Ige, O. I., and Bale, R. B.,2007. Investigation of Dissolution Kinetics of A Nigerian Tantalite Ore in Nitric Acid. J. Min. \& Materials Characterization \& Engineering , 7, (1), 83 - 95.

Baba, A. A.; Adekola, F. A.; Ojutemieden, D. O., and Dada, F. K.,2011. Solvent Extraction of Gold from Hydrochloric Acid-Leached Nigerian Gold Ore by Tributylphosphate. Chem. Bull. "POLITEHNICA" Univ. (Timisoara), 56 (70), 1 .

Bian, X.; Yin, S.; Luo, Y., and Wu, W.,2011. Leaching kinetics of bastnaesite concentrate in $\mathrm{HCl}$ solution, Trans. Nonferrous . Met. Soc. China, 21, 2306 - 2310

Clotilde, A., M., and Mulaba, B. A. F.,2011. Dissolution of oxidised $\mathrm{Co}-\mathrm{Cu}$ ores using hydrochloric acid in the presence of ferrous chloride. Hydrometallurgy, 108 (3-4), 233-236.

El-Afandy, A. H.; Bakhit, F. S.; Yonan, A. A., and Saleh, G. M., 2002. Geology, Geochemistry and radioactivity of Sella-Qash Amir granites, south Eastern Desert, Egypt. Egy. Mineral., 14, $117-140$.

El-Hazek, N.; Lasheen, T. A.; El-Sheikh, R., and Zaki, S. A., 2007. Hydrometallurgical criteria for $\mathrm{TiO} 2$ leaching from Rosetta ilmenite by hydrochloric acid. Hydrometallurgy, 87, (1-2), 45-50.

Gupta, C. K., and Mukherjee, T. K.,1990. Hydrometallurgy in Extraction Processes. CRC Press, Boca Raton, I, 70p.
Haque, K. E., and Laliberté, J. J.,1987. Batch and counter-current acid leaching of uranium ore. Hydrometallurgy, 17 (2), 229-238.

Ibrahim, M. E.; Zalata, A, A.; Assaf, H, S.; Ibrahim, I. H., and Rashed, M. A.,2003. El Sella shear zone, south Eastern Desert, Egypt; An example of vein-type uranium deposit: Egy. J. of Geol., 42(2), $690-704$.

Jinhui, L.; Daoling, X.; Hao, C.; Ruixiang, W., and Yong, L.,2012. Physicochemical factors affecting leaching of laterite ore in hydrochloric acid. Hydrometallurgy, 129-130, 14-18.

Kasper, D.R.; Martin, H.W.; Munsey, L. D.; Bhappu, R. B., and Chase, C. K.,1979. Environmental Assessment of In Situ Mining. United States Dept. of the Interior Bureau of Mines, Open File Report 101-80, 294 p.

Khawassek, Y.M.,2011. Uranium Recovery from Inshas Pilot Plant Unit from El Sela Shear Zone, South Eastern Desert, Egypt, personal communication.

Levenspiel, O.,1999. Chemical reaction engineering, 3rd edition. J.Wiley: New York,

Liang, B.; Chun, L.; Zhang, C., and Zhang, Y., 2005. Leaching kinetics of Panzhihua ilmenite in sulfuric acid. Hydrometallurgy, 76, 173-179

Marczenko, Z.,1976. Spectrophotometric determination of elements. Ellis Horwood Ltd., Coll House, Westergate, Chichester, Sussex, England, Book.

Merritt, R. C., 1971. In: The Extractive Metallurgy of Uranium, Colorado, School of Mines Res. Inst., Golden, Colorado, 83p.

Morse, J. W., and Arvidson, R. S.,2002. The dissolution kinetics of major sedimentary carbonate minerals, J. Earth-Sci. Rev., 58, 51-84

Olanipekun, E.,1999. A kinetic study of the leaching of a Nigerian ilmenite ore by hydrochloric acid. Hydrometallurgy, 53, $1-10$. 
Paspaliaris, Y., and Tsolakis, Y.,1987. Reaction kinetics for the leaching of iron oxides in diasporic bauxite from the Parnassus-Giona Zone (Greece) by hydrochloric acid. Hydrometallurgy, 19, 259- 266.

Regina, O. A., and Okechukwu, D. O.,2012. Kinetic Model for Ukpor Clay Dissolution in Hydrochloric Acid Solution. J. Emerging Trends in Engin. and Appl. Sci., 3 (3), 448-454.

Sohn, H. Y.,2003. Chemical Reaction Engineering in the Chemical Processing of Metals and Inorganic Materials Part I. Advances in Fluid-Solid Reaction Analysis. Korean J. Chem. Engineering, 20 (2), 185.

Tsuchida, H.; Narita, E., and Takeuchi, H., 1982. Manufacture of high pure titanium (IV) oxide by the chloride process; I. Kinetic study on leaching of ilmenite ore in concentrated hydrochloric acid solution. Bull. Chem. Soc. Jpn., 55 (6), 1934- 1938.

Ucar, G., 2009. Kinetics of spahlerite dissolution by sodium chlorate in hydrochloric acid. Hydrometallurgy, 96, 39 - 43.

Wen-tang, X. ;Author, V.; Zheng-de, R., and Yifeng, G.,2011. Removal of Phosphorus From High Phosphorus Iron Ores by Selective $\mathrm{HCl}$ Leaching Method. J. Iron and Steel Res., Inter., $18(5), 1-4$.

Zafar, Iqbal Zafar; Ansari, Tariq Mahmood ; Ashraf, Mohammad, 2006. Effect of Hydrochloric Acid on Leaching Behavior of Calcareous Phosphorites, Iran. J. Chem. Chem. Eng. 25, No.2. 